Research paper

\title{
Design, synthesis and X-ray crystallography of selenides bearing benzenesulfonamide moiety with neuropathic pain modulating effects
}

\author{
Andrea Angeli ${ }^{a}$, Lorenzo di Cesare Mannelli ${ }^{b}$, Elena Lucarini ${ }^{b}$, Thomas S. Peat ${ }^{c}$, \\ Carla Ghelardini ${ }^{\text {b }}$, Claudiu T. Supuran ${ }^{\text {a, * }}$ \\ ${ }^{a}$ Università degli Studi di Firenze, NEUROFARBA Dept., Sezione di Scienze Farmaceutiche, Via Ugo Schiff 6, 50019, Sesto Fiorentino, Florence, Italy \\ ${ }^{\mathrm{b}}$ NEUROFARBA Department, Section of Pharmacology and Toxicology, Università degli Studi di Firenze, Viale Pieraccini 6, 50139, Florence, Italy \\ ${ }^{\text {c } C S I R O,} 343$ Royal Parade, Parkville, Victoria, 3052, Australia
}

\section{A R T I C L E I N F O}

Article history:

Received 14 April 2018

Received in revised form

15 May 2018

Accepted 16 May 2018

Available online 19 May 2018

\section{Keywords:}

Carbonic Anhydrase Inhibitors (CAIs)

Neuropathic pain

Selenium

Metalloenzymes

Organoselenium

\begin{abstract}
A B S T R A C T
A series of selenides bearing benzensulfonamide were investigated as inhibitors of the metalloenzyme carbonic anhydrase (CA, EC 4.2.1.1). Potent inhibitory action, in the low nanomolar range, was detected against isoforms hCA II and VII, which are known to be involved in neuropathic pain modulation. These selenides showed on the other hand moderate inhibition against the cytosolic isoforms hCA I and transmembrane hCA IX. X-ray crystallographic data of two derivatives bound to hCA II allowed us to rationalize the excellent inhibitory data. In a mice model of neuropathic pain induced by oxaliplatin, some of the strong CA II/VII inhibitors induced a long lasting pain relieving effect.
\end{abstract}

๑) 2018 Elsevier Masson SAS. All rights reserved.

\section{Introduction}

Neuropathic pain is a major public health problem that affects approximately $6 \%$ of the adult population worldwide [1]. This condition manifests specific symptoms such as spontaneous burning pain and allodynia (pain that arises due to non-noxious stimuli) due to sensory system damage or disease [1]. Such symptoms have a significant impact on a patient's quality of life and social productivity. Despite several therapeutic options, treatment or control of neuropathic pain remains challenging because of the heterogeneous etiology and the multifactorial mechanisms underlying this disease [2]. Damages to the nervous tissue induce a complex machinery of pathophysiologic events. A peripheral nerve lesion may provoke aberrant regeneration of the nerve, with the neurons becoming unusually sensitive and developing an abnormal excitability called peripheral sensitization $[3,4]$. On the other hand,

\footnotetext{
* Corresponding author.

E-mail address: claudiu.supuran@unifi.it (C.T. Supuran).
}

a central component of pain develops by direct or indirect alterations. The spinothalamic tract neurons develop an increased background activity, coupled to enlarged receptive fields and increased responses to afferent impulses, including the normally innocuous stimuli. These mechanisms together with secondary events in the central pain processing pathways contribute to the development and maintenance of a steady-state pain condition [5]. Recently, pioneering work from Kaila and Price's groups discovered the connection between Carbonic Anhydrases (CAs) modulation and neuropathic pain [6,7]. These metalloenzymes catalyzed efficiently the hydration of $\mathrm{CO}_{2}$ to bicarbonate and protons. Generation of $\mathrm{HCO}_{3}^{-}$as a reaction product of $\mathrm{CO}_{2}$ hydration is closely connected with the physiology/biochemistry of many neurotransmitters, such as $\gamma$-aminobutyric acid (GABA) [8]. CA inhibition with the clinically used sulfonamide acetazolamide (AAZ) augments $G_{A B A}$ receptormediated analgesia via a spinal mechanism of action. In vivo pharmacologic and modeling studies showed that a loss function of the neuron-specific potassium-chloride $\left(\mathrm{K}^{+}-\mathrm{Cl}^{-}\right)$cotransporter $\mathrm{KCC} 2$ leads to a decrease in the efficacy of $\mathrm{GABA}_{\mathrm{A}}$-mediated spinal inhibition [7]. In order to reduced bicarbonate-dependent depolarization via GABAA receptors when the function of KCC2 is 
Table 1

Synthesis of selenides bearing benzenesulfonamide moiety 3a-f.

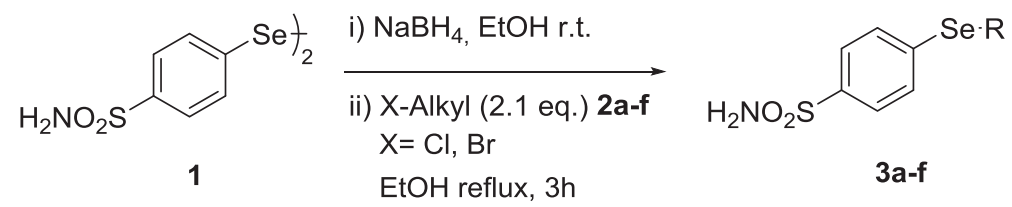

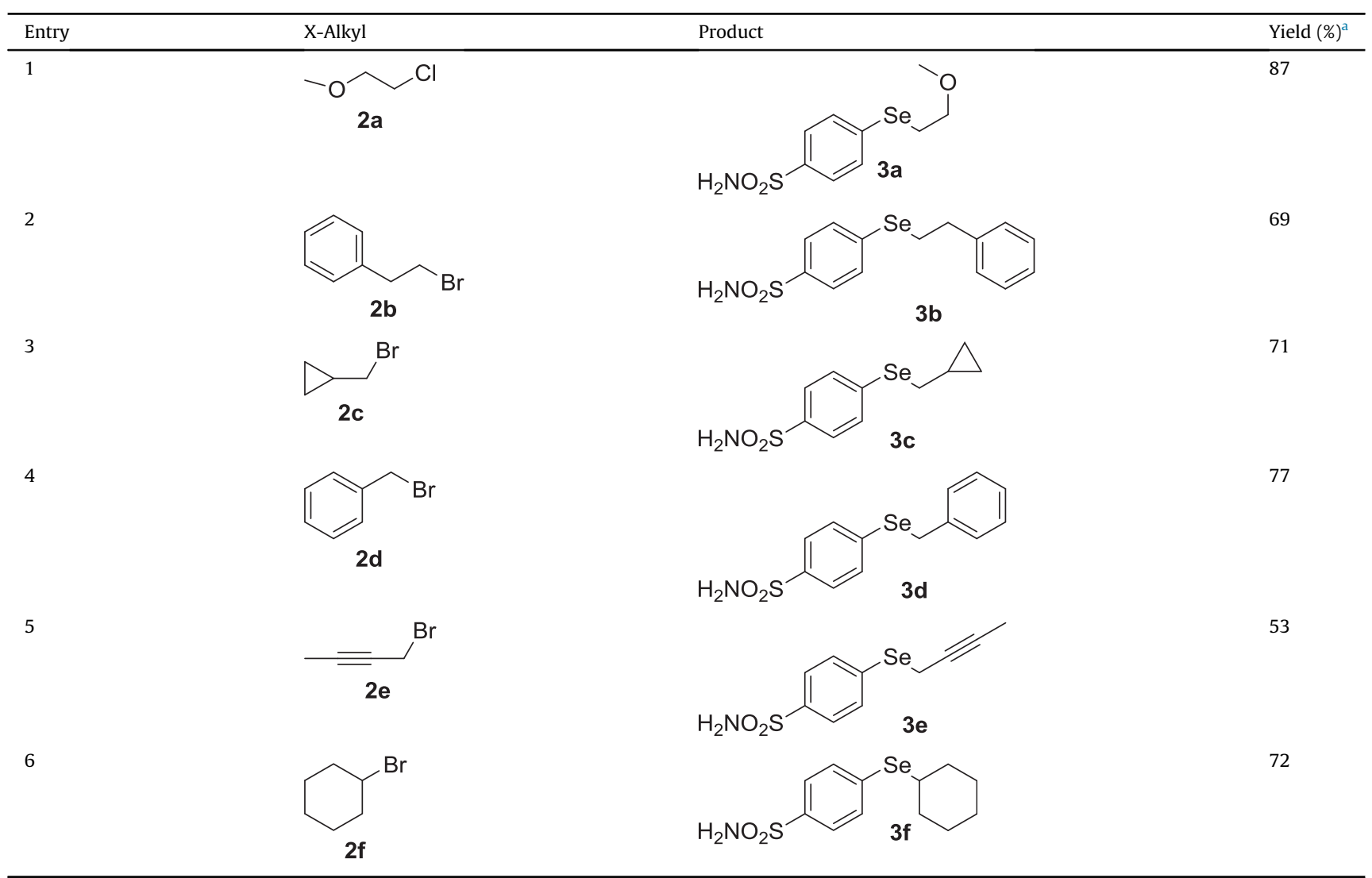

a Yields are referred to isolated products.

compromised, one potential strategy was inhibit CA thus mitigates the negative effects of loss of KCC2 function after nerve injury [8]. The use of CAIs in the management of neuropathic pain [9] and cerebral ischemia [10] showed very interesting results, which might lead to new possibilities of therapeutic applications for this class of compounds.

\section{Results and discussion}

\subsection{Compounds design and synthesis}

The physical damage by chemotherapeutic drugs leads to functional impairment in neurons through oxidative stress,

$$
\mathrm{R}^{-\mathrm{Se}} \mathrm{Se}^{-\mathrm{R}}
$$

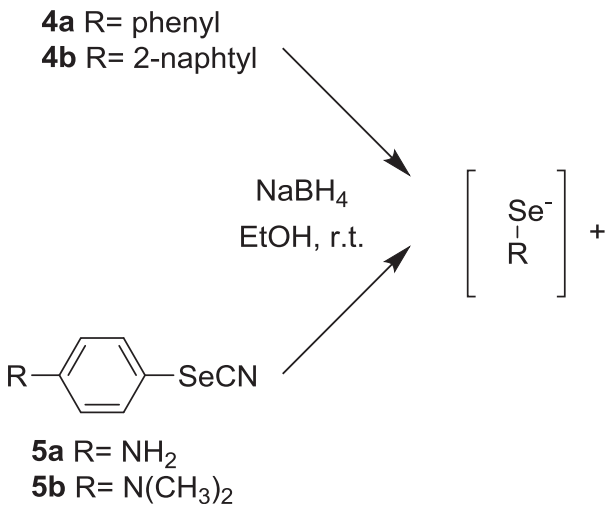<smiles>NS(=O)(=O)c1ccc(CBr)cc1</smiles>

6

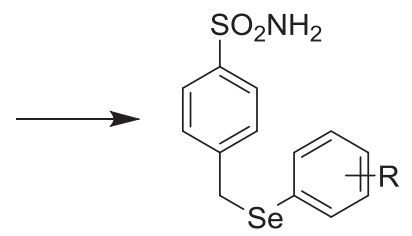

7a $\mathrm{R}=\mathrm{H}$

7b R= 2-naphtyl

7c $\mathrm{R}=4-\mathrm{NH}_{2}$

7d $\mathrm{R}=4-\mathrm{N}\left(\mathrm{CH}_{3}\right)_{2}$

Scheme 1. Synthesis of selenides 7a-d from different diselenides or selenocyanates. 
inflammation, apoptosis and electrophysiological disturbances. In fact, oxidative stress is identified to be responsible for the neuronal damage in different models of neuropathies such as diabetic neuropathy, acryl amide induced neuropathy and Charcot-Marie neuropathy [11-14]. In this particular contest, our drug design is based on the combination of sulfonamide moiety as a typical zinc binding group (ZBG), with the well known antioxidant propriety of organo-selenium [15-17]. 4caffolds 4,4'-Diselanediyldibenzenesulfonamide $\mathbf{1}$ was synthesized from sulfanilamide in three steps using published procedures from our group $[18,19]$, and 1 was then treated with $\mathrm{NaBH}_{4}$ and afterwards, it was treated in situ with the appropriate halo-alkyl derivatives (2a-f) to synthesize the corresponding selenides (3a-f) in good yields (Table 1).

In order to access different selenides, we used different approaches. The synthesis of compounds 7a-b was carried out according to Scheme 1 by using the reduction reaction of diselenides (4a-b) and 4-(bromomethyl) benzenesulfonamide (6) to afford in good yield selenides $\mathbf{7 a - b}$.

Two different amino aromatic selenocyanates (5a-b) were used as an efficient alternative to diselenides to obtain selenides 7c-d as outlined in Scheme 1. The key intermediates selenocyanates were obtained according to literature procedure [20]. Compounds 5a-b were prepared by addition of selenium dioxide to malononitrile in DMSO at room temperature followed by reaction with the corresponding aminoaryl derivatives. The amino function of 7c was next converted into two different moieties: (i) ureido group (10a-c) using the corresponding isocyanate or isothiocyanate (8a-c) in acetonitrile at room temperature as reported previously by our group [21]; (ii) amide group (11a-c), obtained in excellent yield by using the appropriate acyl chloride (9a-c), in THF and triethylamine as reported in Scheme 2.
Finally, the further functionalization of 4-(bromomethyl) benzenesulfonamide $\mathbf{6}$ was achieved by nucleophilic displacement reactions. The reaction of $\mathbf{6}$ with potassium selenocyanate afforded the functionalized 4-methyl benzenesulfonamide in good yields (Scheme 3).

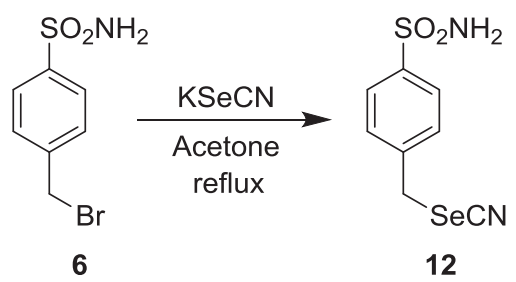

Scheme 3. Synthesis of 4-(selenocyanatomethyl)benzenesulfonamide $\mathbf{1 2}$.

\subsection{Carbonic anhydrase inhibition}

All synthesized compounds, 3a-f, 7a-d, 10a-c, 11a-c and 12, were tested in vitro for their inhibitory properties against the physiological relevant hCA isoforms (I, II, VII, and IX) by means of a stopped-flow carbon dioxide hydration assay [22] after a period of $15 \mathrm{~min}$ of incubation of the enzyme and inhibitor solutions [23-27]. Their activities were compared to the standard carbonic anhydrase inhibitor (CAI) acetazolamide (AAZ) (Table 2).

The following SARs for the hCA isoforms considered are reported:

i) The ubiquitous cytosolic hCA I was weakly inhibited by all compounds except for $\mathbf{3 f}$ which showed a good inhibition

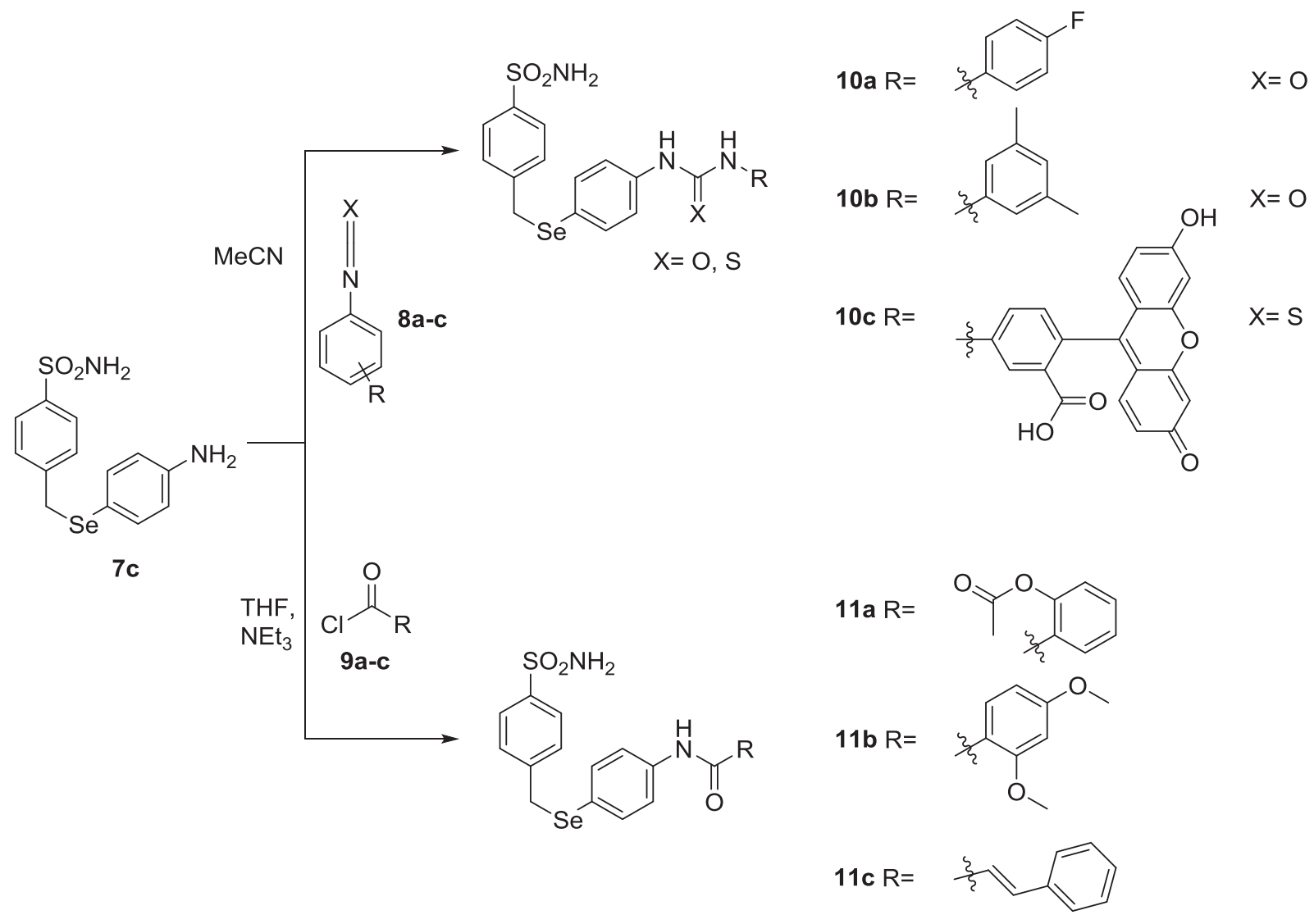

Scheme 2. Synthesis of new selenides with ureido (10a-c) and amido (11a-c) groups. 
Table 2

Inhibition data of human CA isoforms I, II, VII and IX with compounds 3a-f, 7a-d, 10a-c, 11a-c, 12 and $\mathbf{A A Z}$ by a stopped flow $\mathrm{CO}_{2}$ hydrase assay [22].

\begin{tabular}{|c|c|c|c|c|}
\hline \multirow[t]{2}{*}{$\mathrm{Cmp}$} & \multicolumn{4}{|c|}{$\mathrm{K}_{\mathrm{I}}(\mathrm{nM})^{\mathrm{b}}$} \\
\hline & hCA I & hCA II & hCA VII & hCA IX \\
\hline $3 a^{a}$ & 261.7 & 41.2 & 0.77 & 12.0 \\
\hline $\mathbf{3 b}^{\mathrm{a}}$ & 256.8 & 9.3 & 0.31 & 8.7 \\
\hline $3 c$ & 73.5 & 4.9 & 7.2 & 46.4 \\
\hline 3d & 531.2 & 3.9 & 1.8 & 548.6 \\
\hline $3 e^{a}$ & 293.5 & 7.6 & 2.0 & 2.2 \\
\hline $3 \mathbf{f}^{\mathrm{a}}$ & 21.9 & 6.3 & 0.24 & 2.6 \\
\hline $7 a$ & 226.1 & 53.0 & 6.6 & 2.7 \\
\hline $7 b$ & 953.7 & 70.8 & 645.0 & 337.4 \\
\hline 7c & 464.3 & 1.5 & 17.4 & 286.3 \\
\hline 7d & 841.1 & 46.9 & 311.8 & 450.1 \\
\hline $10 a$ & 4767 & 220.5 & 295.6 & 1071 \\
\hline $10 b$ & 926.8 & 6.0 & 86.0 & 1137 \\
\hline $10 c$ & 755.4 & 0.94 & 3.8 & 697.4 \\
\hline 11a & 93.3 & 0.54 & 0.93 & 709.8 \\
\hline 11b & 5995 & 9.4 & 37.4 & 845.0 \\
\hline 11c & 2578 & 364.6 & 462.8 & 1006 \\
\hline 12 & 70.2 & 14.0 & 0.97 & 4.0 \\
\hline AAZ & 250 & 12.1 & 2.5 & 25.8 \\
\hline
\end{tabular}

a Reference [19].

b Mean from 3 different assays, by a stopped flow technique (errors were in the range of $\pm 5-10 \%$ of the reported values).

potency with $K_{i}$ of $21.9 \mathrm{nM}$. The different tails of derivatives 3a-e and 7a-c did not modified significantly the activity. On the other hand, the efficacy decreased to micromolar range for the next functionalization of compound $7 \mathbf{c}$ with ureido (10a-c) and amido (11a-c) moieties, except for 11a with $K_{i}$ of $93.3 \mathrm{nM}$.

ii) The in vitro kinetic data showed that ureido 10c and amido derivatives 11a were the most potent inhibitors against the dominant cytosolic human isoform hCA II, in sub nanomolar range ( $\mathrm{K}_{\mathrm{i}} 0.94$ and $0.54 \mathrm{nM}$ respectively), followed by the compounds in series 3a-f $\left(K_{i} 3.9-41.2 \mathrm{nM}\right)$. Low-medium inhibition potencies, with $K_{i}$ values spanning between 220.5 and $364.6 \mathrm{nM}$, were obtained for compounds 10a and 11c.

iii) The last cytosolic human isoform studied here, hCA VII, was potently inhibited by many compounds investigated in the present article, in the sub or low-medium nanomolar range, except for derivatives 7c, 10a and 11c which were active in the high nanomolar range ( $\left.K_{i} 295.6-645.0 \mathrm{nM}\right)$. Conversely, the different moieties of derivatives $\mathbf{3 a - f}$ and $\mathbf{7 a - c}$ influenced the activity, leading to a decrease of inhibition potency of over ten times for compounds 7a-c. Successive functionalization of compound 7c with different ureido (10a-c) and amido (11a-c) scaffolds proved to strongly change their inhibition profile against hCA VII, with some derivatives acting as highly efficient and other as much less efficient hCA VII inhibitors.

iv) Similar to hCA I, the transmembrane tumor-associated hCA IX, was weakly inhibited by almost all compounds investigated here, which showed $\mathrm{K}_{\mathrm{I}} \mathrm{S}$ in the high nanomolar range. Ureido and amido substituents (10a-c and 11a-c), did not influence the efficacy of inhibition. On the other hand, the different moieties of selenides in the compounds series 3a-f showed multiplicity of inhibition profiles, thus proving to be crucial for the modulation of this isoform inhibition.

\subsection{Structure of hCA II/Selenides ligand complex}

Recent studies reported an enhanced expression of some cytosolic human CA isoforms (among which hCA II) in states connected to chronic pain, such as thrombus-induced ischemic pain [28], or chronic musculoskeletal pain in humans [29]. Thus, we next determined the protein X-ray crystal structure of hCA II in complex with compounds $3 \mathbf{e}$ and $\mathbf{3 f}$ (Fig. 1), in order to obtain an insight into ligand-protein interactions at the atomic level. Selenides bearing sulphonamide moieties 3e-f contain a short hydrophobic tail and they were soaked into crystals of hCA II. In the absence of an inhibitor the $\mathrm{Zn}(\mathrm{II})$ ion is tetrahedrally coordinated by His94, His96 and His119 (hCA II numbering system labeled in blue in Fig. 1) and a water molecule or hydroxyl ion.

In each protein-inhibitor complex, the conserved zinc-bound water molecule is displaced by inhibitors $\mathbf{3 e}$ and $\mathbf{3 f}$, while additional hydrogen bond interactions with residue Thr199 further contribute to stabilize the binding (Fig. 1). The hydrophobic tail of the inhibitors is rather peculiarly oriented, in both cases, in both cases, are located in the hydrophobic region of the active site in a small pocket delimited by residues Val 121, Phe131, Val135, Leu198, and Pro202. We observed some different interactions in hydrophobic region between inhibitors, where, cyclohexane tail of compound $3 \mathbf{f}$ was in close proximity of Phe131, on the other hand, butyne tail of selenide $\mathbf{3 e}$ showed more hydrophobic interactions with Val 135 and Leu204 residues (Fig. 1 A).

\subsection{Biological assays}

All these compounds are potent inhibitors of several physiologically relevant CA isoforms, such as hCA I, II, VII and IX. On the other hand, there is not a precise knowledge which CA isoforms are involved in the neuropathic pain response. For this reason, we focused our attention on several cytosolic and transmembrane CAs which are present in the central/peripheral nervous system such as CA I, II, VII (the last one was predominantly expressed in the brain and being absent in most other tissues) and CA IX (transmembrane isoforms). Thus, we investigated different selenides such as $\mathbf{3 a - b}$ and $\mathbf{7 a}$ in comparison to acetazolamide (AAZ), as possible pain relievers in a mice model of neuropathic pain induced by oxaliplatin [30,31] (Fig. 2). This platinum derivative has become a valid option as adjuvant therapy in several types of cancer [9,31]. However, a possible side effect is a painful neuropathy correlated with characteristic alterations of the nervous system leading to a negative influence on patients' quality of life [9,31].

Mice were repeatedly treated intraperitoneally with oxaliplatin $\left(2.4 \mathrm{mg} \mathrm{kg}^{-1}\right)$ for 5 consecutive days every week for 2 weeks till to development of a significant painful neuropathy [31]. O day 14, a single administration of compounds $\mathbf{3 a - b}$ and $\mathbf{7 a}$ significantly reduced the lowering of pain threshold to cold stimuli. All selenides, here considered, relieved pain dose-dependently (3-100 $\mathrm{mg} \mathrm{kg}^{-1}$ p.o.). Compounds 3a-b showed a significant pain relief to higher dose $\left(100 \mathrm{mg} \mathrm{kg}^{-1}\right.$ p.o.) between 15 and $45 \mathrm{~min}$ after treatment. More effective was 7a able to restore almost the normal pain threshold at $30 \mathrm{~min}$ with already $30 \mathrm{mg} \mathrm{kg}^{-1}$. In the same model, effective of $\mathbf{A A Z}$ was limited to $15 \mathrm{~min}$, moreover, the potency and efficacy of selenides compared to $\mathbf{A A Z}$ were much higher.

\section{Conclusions}

We have designed, synthesized and obtained the X-ray crystallographic structure of a novel series of selenides bearing benzenesulfonamide moieties as inhibitors of four $\alpha$-carbonic anhydrases (CAs, EC 4.2.1.1) of pharmacologic relevance, i.e., hCA I, II, VII and IX. These selenides showed moderate inhibition against the cytosolic isoforms hCA I and IX, but were generally effective, low and sub nanomolar CA II, VII inhibitors. Several cytosolic and transmembrane CAs are present in the central/peripheral nervous 


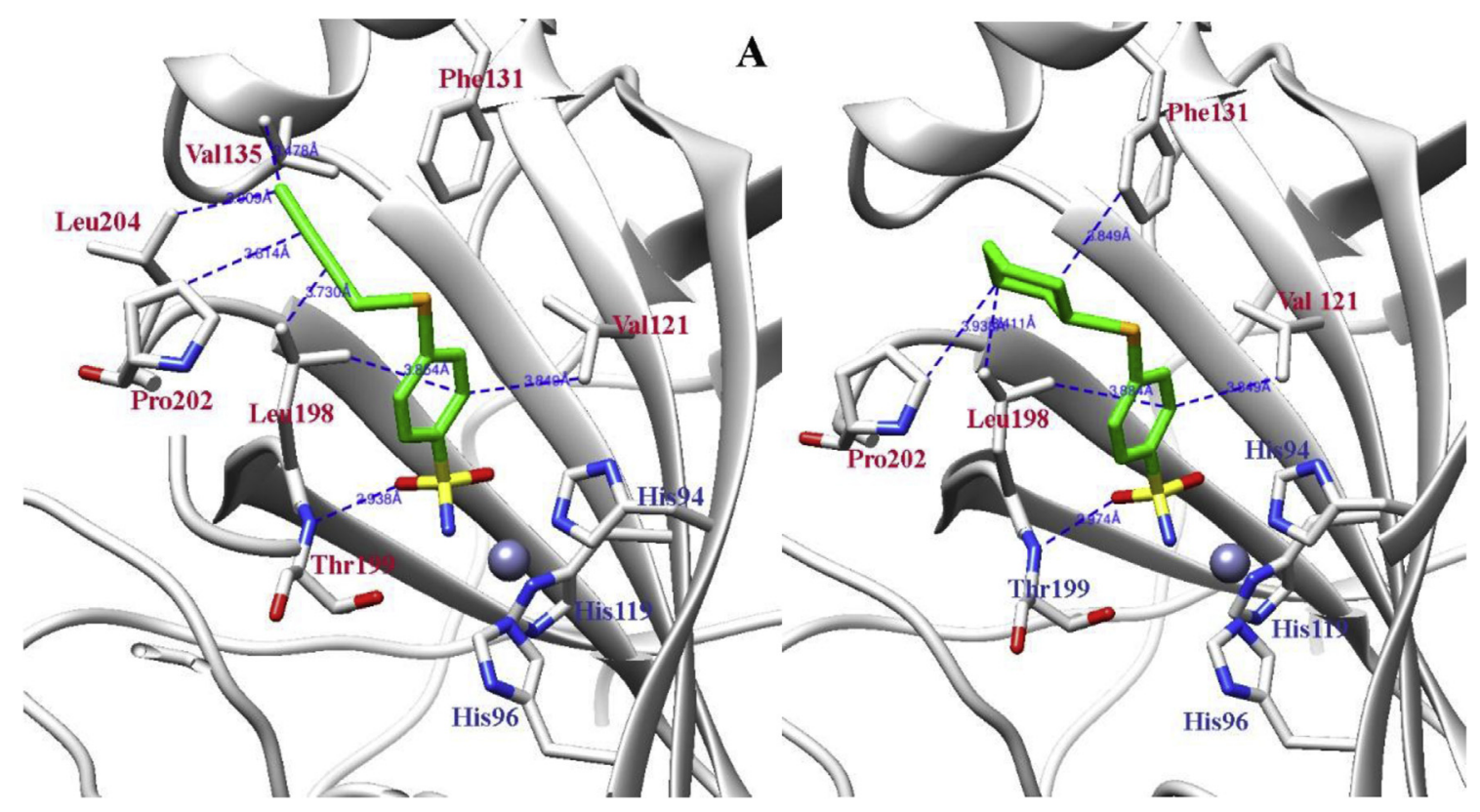

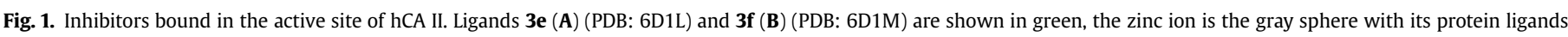

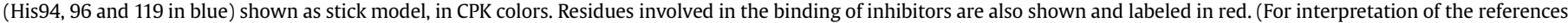
to color in this figure legend, the reader is referred to the Web version of this article.)

system and their inhibition showed in a mice model of neuropathic pain induced by oxaliplatin a long lasting pain relieving effect.

\section{Experimental part}

\subsection{Chemistry}

Anhydrous solvents and all reagents were purchased from Sigma-Aldrich, Alfa Aesar and TCI. All reactions involving air- or moisture-sensitive compounds were performed under a nitrogen atmosphere using dried glassware and syringes techniques to transfer solutions. Nuclear magnetic resonance $\left({ }^{1} \mathrm{H}\right.$ NMR, ${ }^{13} \mathrm{C}$ NMR, ${ }^{19} \mathrm{~F}$ NMR, ${ }^{77}$ Se-NMR, DEPT-135, DEPT-90, HSQC, HMBC) spectra were recorded using a Bruker Advance III $400 \mathrm{MHz}$ spectrometer in DMSO- $d_{6}$. $(\mathrm{PhSe})_{2}$ was used as an external reference for ${ }^{77} \mathrm{Se}$ NMR $(\delta=461 \mathrm{ppm})$. Chemical shifts are reported in parts per million (ppm) and the coupling constants $(J)$ are expressed in Hertz (Hz). Splitting patterns are designated as follows: s, singlet; $d$, doublet; $t$, triplet; q, quadruplet; m, multiplet; brs, broad singlet; dd, double of doublets. The assignment of exchangeable protons $(\mathrm{OH}$ and $\mathrm{NH})$ was confirmed by the addition of $\mathrm{D}_{2} \mathrm{O}$. Analytical thin-layer chromatography (TLC) was carried out on Merck silica gel F-254 plates. Flash chromatography purifications were performed on Merck Silica gel 60 (230-400 mesh ASTM) as the stationary phase and ethyl acetate/ $n$-hexane were used as eluents. Melting points (mp) were measured in open capillary tubes with a Gallenkamp MPD350.BM3.5 apparatus and are uncorrected.

The solvents used in MS measures were acetone, acetonitrile (Chromasolv grade), purchased from Sigma-Aldrich (Milan - Italy), and $\mathrm{mQ}$ water $18 \mathrm{M} \Omega$, obtained from Millipore's Simplicity system (Milan-Italy). The mass spectra were obtained using a Varian $1200 \mathrm{~L}$ triple quadrupole system (Palo Alto, CA, USA) equipped by Electrospray Source (ESI) operating in both positive and negative ions. Stock solutions of analytes were prepared in acetone at $1.0 \mathrm{mg} \mathrm{mL}^{-1}$ and stored at $4{ }^{\circ} \mathrm{C}$. Working solutions of each analyte were freshly prepared by diluting stock solutions in a mixture of $\mathrm{mQ} \mathrm{H}_{2} \mathrm{O} / \mathrm{ACN} 1$ / $1(v / v)$ up to a concentration of $1.0 \mu \mathrm{g} \mathrm{mL}^{-1}$ The mass spectra of each analyte were acquired by introducing, via syringe pump at $10 \mu \mathrm{L} \mathrm{min}^{-1}$, of the its working solution. Raw-data were collected and processed by Varian Workstation Vers. 6.8 software.

\subsubsection{General procedure for the synthesis of compound $3 \boldsymbol{a}-\boldsymbol{f}$}

$\mathrm{NaBH}_{4}(23 \mathrm{mg}, 0.60 \mathrm{mmol}, 3.0$ eq.) was portionwise added to a solution of $4,4^{\prime}$-diselanediyldibenzenesulfonamide 1 (94 mg, $0.20 \mathrm{mmol}, 1.0$ eq. $)$ in EtOH $(2 \mathrm{~mL})$ at $0{ }^{\circ} \mathrm{C}$ under inert atmosphere $\left(\mathrm{N}_{2}\right)$. After $30 \mathrm{~min}$, the halo-alkyl 2a-f $(0.36 \mathrm{mmol}, 2.1$ eq.) was slowly added and the reaction mixture was stirred at reflux for $3 \mathrm{~h}$, until complete consumption of the starting material was observed by TLC. The reaction was quenched by addition of saturated aq. $\mathrm{NH}_{4} \mathrm{Cl}(2 \mathrm{~mL})$ and diluted with EtOAc $(5 \mathrm{~mL})$. The layers were separated and the aqueous layer was extracted with EtOAc $(2 \times 5 \mathrm{~mL})$, dried over $\mathrm{Na}_{2} \mathrm{SO}_{4}$, filtered and concentrated under vacuum. The crude material was purified by flash chromatography to yield selenides (3a-f) bearing benzenesulfonamide moiety.

\subsubsection{4-((cyclopropylmethyl)selanyl)benzenesulfonamide 3c}<smiles>NS(=O)(=O)c1ccc([Se]CC2CC2)cc1</smiles>

Following the general procedure, 4,4'-diselanediyldibenzenesulfonamide $1(100 \mathrm{mg}, 0.21 \mathrm{mmol})$ and (bromomethyl)cyclopropane $2 \mathrm{c}(60 \mathrm{mg}, 0.44 \mathrm{mmol})$ gave after flash chromatography (hexane/EtOAc 1:1) 3c (91 mg, 71\%). ${ }^{\mathbf{1}} \mathbf{H}$ NMR (400 MHz, DMSO- $\left.d_{6}\right) \delta(\mathrm{ppm}): 7.72(2 \mathrm{H}, \mathrm{d}, J=8.61 \mathrm{~Hz}), 7.67(2 \mathrm{H}, \mathrm{d}$, $J=8.58 \mathrm{~Hz}), 7.37\left(2 \mathrm{H}, \mathrm{bs}, \mathrm{NH}_{2}\right.$, exchange with $\left.\mathrm{D}_{2} \mathrm{O}\right), 3.08(2 \mathrm{H}, \mathrm{d}$, $J=7.25 \mathrm{~Hz}), 1.14-1.07(1 \mathrm{H}, \mathrm{m}), 0.61-0.60(2 \mathrm{H}, \mathrm{m}), 0.31-0.29(2 \mathrm{H}$, $\mathrm{m}) .{ }^{13} \mathrm{C}$ NMR (100 MHz, DMSO-d $\left.d_{6}\right) \delta(\mathrm{ppm}): 142.6,137.5,131.3,127.1$, 32.9, 12.0, 7.7. ${ }^{77}$ Se NMR (76 MHz, DMSO- $\left.d_{6}\right) \delta(\mathrm{ppm}): 303.6$. MS (ESI negative) $m / z: 290.1[\mathrm{M}-\mathrm{H}]^{-}$, 

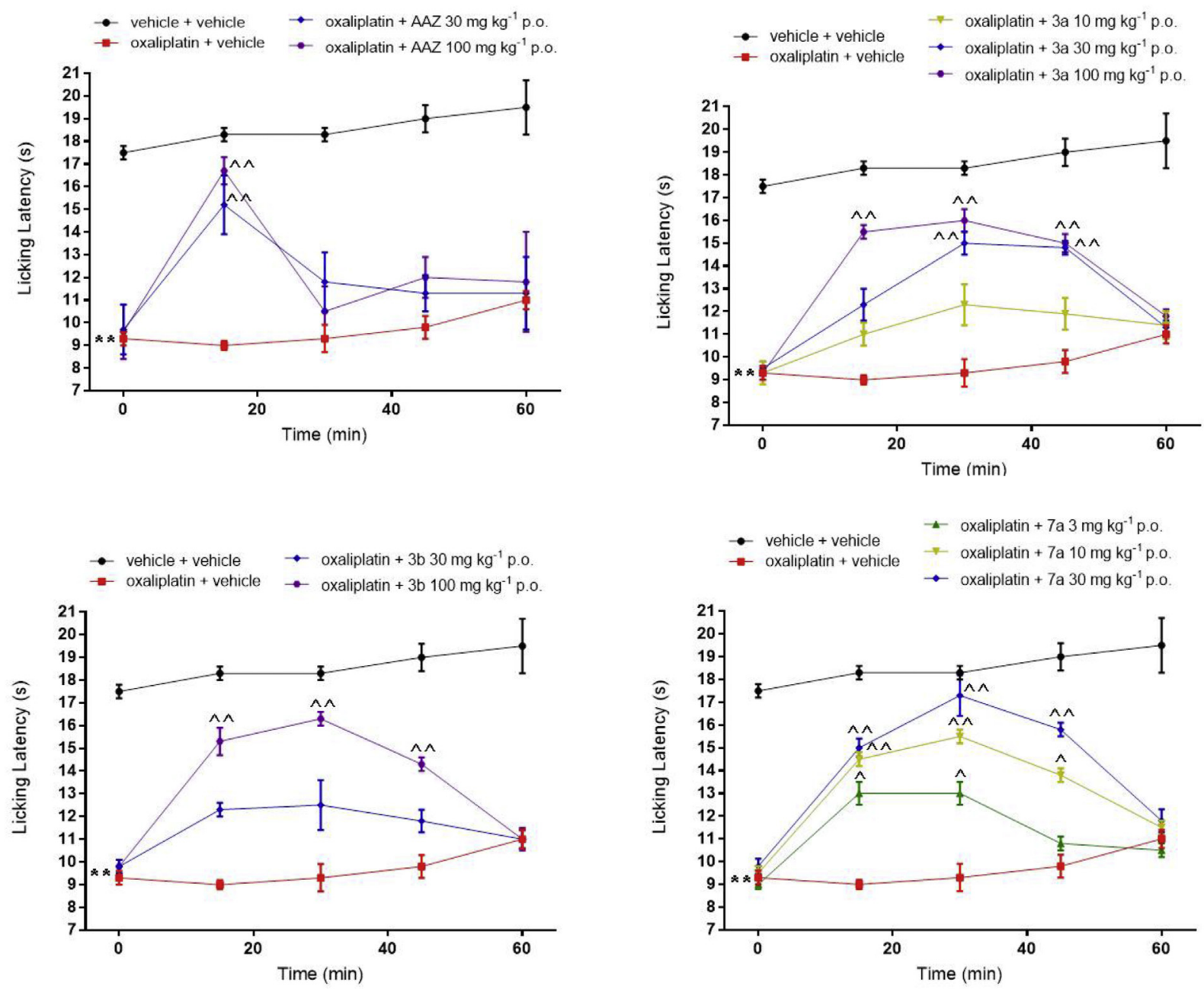

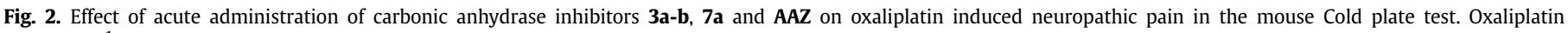

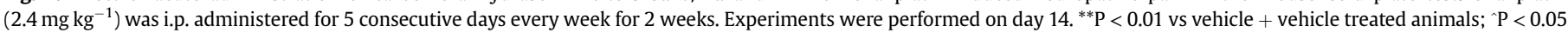
and ${ }^{\wedge} \mathrm{P}<0.01$ vs oxaliplatin + vehicle treated animals. Each value represents the mean \pm S.E.M. of 10 mice performed in 2 different experimental sets.

\subsubsection{4-(benzylselanyl)benzenesulfonamide $3 \boldsymbol{d}$}<smiles>NS(=O)(=O)c1ccc(OCc2ccccc2)cc1</smiles>

Following the general procedure, 4,4'-diselanediyldibenzenesulfonamide 1 (100 $\mathrm{mg}, 0.21 \mathrm{mmol}$ ) and benzyl bromide $2 \mathbf{d}(75 \mathrm{mg}, 0.44 \mathrm{mmol})$ gave after flash chromatography (hexane/EtOAc 1:1) 3d (110 mg, 77\%). ${ }^{\mathbf{1}} \mathbf{H}$ NMR (400 MHz, DMSO$\left.d_{6}\right) \delta$ (ppm): $7.70(4 \mathrm{H}, \mathrm{apq}), 7.40-7.39(4 \mathrm{H}, \mathrm{m}), 7.34-7.30(2 \mathrm{H}, \mathrm{m})$, $7.26-7.23(1 \mathrm{H}, \mathrm{m}), 4.39(2 \mathrm{H}, \mathrm{s}) .{ }^{13} \mathrm{C}$ NMR $\left(100 \mathrm{MHz}, \mathrm{DMSO}-d_{6}\right)$ $\delta(\mathrm{ppm}): 143.0,139.0,137.1,131.6,129.8,129.3,127.9,127.0,30.8$. ${ }^{77}$ Se NMR (76 MHz, DMSO- $\left.d_{6}\right) \delta(\mathrm{ppm}): 367,7$. MS (ESI negative) $\mathrm{m} /$ $z: 326.1[\mathrm{M}-\mathrm{H}]^{-}$.

\subsubsection{General procedure for the synthesis of selenides $7 \mathbf{a}-\mathbf{b}$}

$\mathrm{NaBH}_{4}(0.60 \mathrm{mmol}, 3.0$ eq.) was portionwise added to a solution of diselenides $\mathbf{4 a - b}(0.20 \mathrm{mmol}, 1.0$ eq.) in EtOH $(5 \mathrm{~mL})$ at room temperature under inert atmosphere $\left(\mathrm{N}_{2}\right)$. After $30 \mathrm{~min}$, sulphonamide $6(0.40 \mathrm{mmol}, 2.0$ eq.) was slowly added and the reaction mixture was stirred at room temperature for $3 \mathrm{~h}$, until complete consumption of the starting material was observed by TLC. The reaction was quenched by addition of saturated aq. $\mathrm{NH}_{4} \mathrm{Cl}(4 \mathrm{~mL})$ and diluted with EtOAc $(5 \mathrm{~mL})$. The layers were separated and the aqueous layer was extracted with EtOAc $(2 \times 5 \mathrm{~mL})$, dried over $\mathrm{Na}_{2} \mathrm{SO}_{4}$, filtered and concentrated under vacuum. The crude material was purified by flash chromatography (hexane/EtOAc 1:1) to yield selenides $\mathbf{7 a - b}$.

\subsubsection{4-((naphthalen-2-ylselanyl)methyl)benzenesulfonamide $\mathbf{7 b}$}

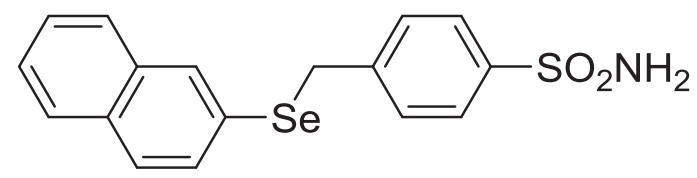

Following the general procedure, 1,2-di(naphthalen-2-yl)diselenide $4 \mathbf{b}$ ( $83 \mathrm{mg}, 0.20 \mathrm{mmol}$ ) and 4-(bromomethyl) benzenesulfonamide 6 (100 $\mathrm{mg}, \quad 0.40 \mathrm{mmol})$ gave after flash chromatography (hexane/EtOAc $1: 1)$ 7b $(215 \mathrm{mg}, 70 \%) .{ }^{\mathbf{1}} \mathbf{H}$ NMR (400 MHz, DMSO- $\left.d_{6}\right) \delta(\mathrm{ppm}): 8.07(1 \mathrm{H}, \mathrm{s}), 7.89-7.84(3 \mathrm{H}, \mathrm{m}), 7.72$ $(2 \mathrm{H}, \mathrm{d}, J=8.41 \mathrm{~Hz}), 7.66-7.64(2 \mathrm{H}, \mathrm{m}), 7.56-7.51(3 \mathrm{H}, \mathrm{m}), 7.31(2 \mathrm{H}$, bs, $\mathrm{NH}_{2}$, exchange with $\left.\mathrm{D}_{2} \mathrm{O}\right), 4.45(2 \mathrm{H}, \mathrm{s}) .{ }^{13} \mathrm{C}$ NMR $(100 \mathrm{MHz}$, 
DMSO-d $\left.d_{6}\right) \delta(\mathrm{ppm}): 144.2,143.3,134.4,132.6,131.1,130.4,130.1$, 129.3, 128.6, 128.4, 128.0, 127.6, 127.0, 126.6, 30.5. ${ }^{77}$ Se NMR (76 MHz, DMSO- $\left.d_{6}\right) \delta(\mathrm{ppm}): 375.9$. MS (ESI negative) $\mathrm{m} / z: 376.1$ $[\mathrm{M}-\mathrm{H}]^{-}$.

\subsubsection{General procedure for the synthesis of selenides 7c-d}

$\mathrm{NaBH}_{4}(0.80 \mathrm{mmol}, 4.0$ eq.) was portionwise added to a solution of arylselenocyanates $\mathbf{5 a - b}(0.20 \mathrm{mmol}, 1.0$ eq. $)$ in EtOH $(5 \mathrm{~mL})$ at room temperature under inert atmosphere $\left(\mathrm{N}_{2}\right)$. After $1 \mathrm{~h}$, sulphonamide 6 ( $0.20 \mathrm{mmol}, 1.0$ eq.) was slowly added and the reaction mixture was stirred at room temperature for $3 \mathrm{~h}$, until complete consumption of the starting material was observed by TLC. The reaction was quenched by addition of saturated aq. $\mathrm{NH}_{4} \mathrm{Cl}$ $(4 \mathrm{~mL})$ and diluted with EtOAc $(5 \mathrm{~mL})$. The layers were separated and the aqueous layer was extracted with EtOAc $(2 \times 5 \mathrm{~mL})$, dried over $\mathrm{Na}_{2} \mathrm{SO}_{4}$, filtered and concentrated under vacuum. The crude material was purified by flash chromatography (hexane/EtOAc 1:1) to yield selenides $\mathbf{7 c - d}$.

\subsubsection{4-(((4-aminophenyl)selanyl)methyl)benzenesulfonamide 7c}

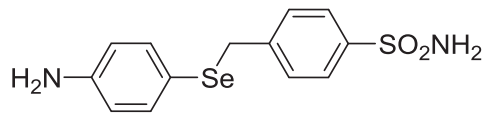

Following the general procedure, 4-selenocyanatoaniline 5a ( $40 \mathrm{mg}, 0.20 \mathrm{mmol}$ ) and 4-(bromomethyl) benzenesulfonamide 6 (50 mg, $0.20 \mathrm{mmol}$ ) gave after flash chromatography (hexane/ EtOAc 1:1) 7c (58 mg, 85\%). ${ }^{1} \mathbf{H}$ NMR (400 MHz, DMSO- $\left.d_{6}\right) \delta(\mathrm{ppm})$ : $7.70(2 \mathrm{H}, \mathrm{d}, J=8.36 \mathrm{~Hz}), 7.36-7.29(4 \mathrm{H}, \mathrm{m}), 7.12(2 \mathrm{H}, \mathrm{d}, J=8.51 \mathrm{~Hz})$, $6.50(2 \mathrm{H}, \mathrm{d}, J=8.53 \mathrm{~Hz}), 5,32\left(2 \mathrm{H}, \mathrm{bs}, \mathrm{NH}_{2}\right.$, exchange with $\left.\mathrm{D}_{2} \mathrm{O}\right), 4.05$ $(2 \mathrm{H}, \mathrm{s}) .{ }^{13} \mathrm{C}$ NMR $\left(100 \mathrm{MHz}, \mathrm{DMSO}-d_{6}\right) \delta$ (ppm): $149.8,145.0,143.0$, $136.9,129.8,126.4,115.5,113.3,32.5 .{ }^{77}$ Se NMR (76 MHz, DMSO-d $\left.d_{6}\right)$ $\delta$ (ppm): 370.7. MS (ESI negative) $m / z: 341.2[\mathrm{M}-\mathrm{H}]^{-}$.

\subsubsection{4-(((4-(dimethylamino)phenyl)selanyl)methyl)} benzenesulfonamide $7 \boldsymbol{d}$

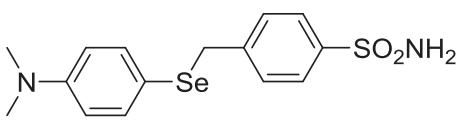

Following the general procedure, N,N-dimethyl-4selenocyanatoaniline $\mathbf{5 b}(45 \mathrm{mg}, 0.20 \mathrm{mmol})$ and 4-(bromomethyl) benzenesulfonamide $\mathbf{6}(50 \mathrm{mg}, 0.20 \mathrm{mmol})$ gave after flash chromatography (hexane/EtOAc 1:1) 7c (66 mg, 90\%). ${ }^{\mathbf{1}} \mathbf{H}$ NMR (400 MHz, DMSO- $\left.d_{6}\right) \delta(\mathrm{ppm}): 7.70(2 \mathrm{H}, \mathrm{d}, J=8.29 \mathrm{~Hz}), 7.36-7.28$ $(6 \mathrm{H}, \mathrm{m}), 6.66(2 \mathrm{H}, \mathrm{d}, J=8.83 \mathrm{~Hz}), 4.10(2 \mathrm{H}, \mathrm{s}), 2.93(6 \mathrm{H}, \mathrm{s}) .{ }^{13} \mathrm{C}$ NMR $\left(100 \mathrm{MHz}, \mathrm{DMSO}-d_{6}\right) \delta(\mathrm{ppm}): 151.0,144.9,143.0,136.5,129.9,126.5$, 114.2, 113.8, 40.8, 32.4. ${ }^{77}$ Se NMR (76 MHz, DMSO-d 6 ) $\delta$ (ppm): 365.4. MS (ESI positive) $m / z: 371.2[\mathrm{M}+\mathrm{H}]^{+}$.

\subsubsection{General procedure for the synthesis of selenides 10a-c}

Compound 7c $(0.20 \mathrm{mmol})$ was dissolved in acetonitrile $(5 \mathrm{~mL})$ and then treated with a stoichiometric amount of isocyanates 8a-b or isothiocyanate $\mathbf{8 c}$. The mixture was stirred at room temperature until completion (TLC monitoring). The heavy precipitate formed was filtered off, washed with diethyl ether $(10 \mathrm{~mL})$, and dried in vacuo. The crude material was purified by flash chromatography (hexane/Acetone 1:1) to yield selenides 10a-c.
4.1.10. 4-(((4-(3-(4-fluorophenyl)ureido)phenyl)selanyl)methyl) benzenesulfonamide $10 a$

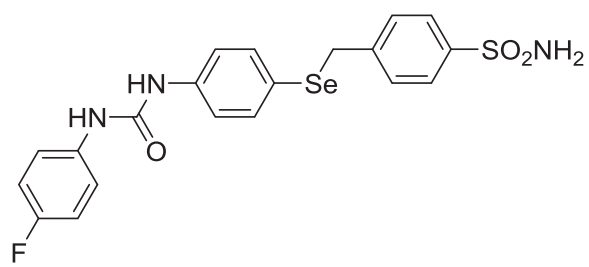

Following the general procedure, 4-((4-aminophenyl)selanyl) methyl)benzenesulfonamide 7c $(68 \mathrm{mg}, 0.20 \mathrm{mmol})$ and 4Fluorophenyl isocyanate $\mathbf{8 a}(34 \mathrm{mg}, 0.20 \mathrm{mmol})$ gave after flash chromatography (hexane/Acetone 1:1) 10a (76 mg, 80\%). ${ }^{\mathbf{1}} \mathbf{H}$ NMR (400 MHz, DMSO- $\left.d_{6}\right) \delta(\mathrm{ppm}): 10.26\left(2 \mathrm{H}, \mathrm{bs}, \mathrm{NH}_{2}\right.$, exchange with $\left.\mathrm{D}_{2} \mathrm{O}\right), 7.70(2 \mathrm{H}, \mathrm{d}, J=8.37 \mathrm{~Hz}), 7.55(2 \mathrm{H}, \mathrm{d}, J=8.67 \mathrm{~Hz}), 7.44-7.37$ $(6 \mathrm{H}, \mathrm{m}), 7.32\left(2 \mathrm{H}, \mathrm{bs}, \mathrm{NH}_{2}\right.$, exchange with $\left.\mathrm{D}_{2} \mathrm{O}\right), 7.19(2 \mathrm{H}, \mathrm{t}$, $J=8.93 \mathrm{~Hz}) 4.25(2 \mathrm{H}, \mathrm{s}) .{ }^{13} \mathrm{C}$ NMR $\left(100 \mathrm{MHz}\right.$, DMSO-d $\left.{ }_{6}\right) \delta(\mathrm{ppm})$ : $170.0,162.0(\mathrm{~d}, J=242.13 \mathrm{~Hz}), 144.4,143.2,139.5,134.5,132.9$ (d, $J=3.15 \mathrm{~Hz}), 131.9(\mathrm{~d}, J=8.03 \mathrm{~Hz}), 130.0,126.5,123.6,120.7,115.9(\mathrm{~d}$, $J=21.20 \mathrm{~Hz}$ ), 43.2. ${ }^{19}$ F-NMR (376 MHz, DMSO- $\left.d_{6}\right) \delta(\mathrm{ppm}):-116.5$. ${ }^{77}$ Se NMR (76 MHz, DMSO- $\left.d_{6}\right) \delta(\mathrm{ppm})$ : 373.8. MS (ESI negative) $\mathrm{m} /$ $z: 477.2[\mathrm{M}-\mathrm{H}]^{-}$.

\subsubsection{4-(((4-(3-(3,5-dimethylphenyl)ureido)phenyl)selanyl) methyl)benzenesulfonamide $\mathbf{1 0 b}$}

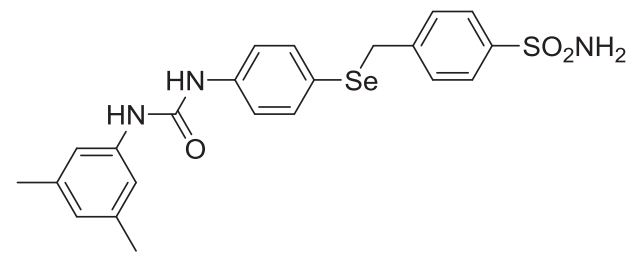

Following the general procedure, 4-((4-aminophenyl)selanyl) methyl)benzenesulfonamide 7c $(68 \mathrm{mg}, 0.20 \mathrm{mmol})$ and 3,5 dimethyl phenyl isocyanate $\mathbf{8 b}(29 \mathrm{mg}, 0.20 \mathrm{mmol})$ gave after flash chromatography (hexane/Acetone $1: 1) \mathbf{1 0 b}(81 \mathrm{mg}, 83 \%) .{ }^{\mathbf{1}} \mathbf{H}$ NMR $\left(400 \mathrm{MHz}, \mathrm{DMSO}-d_{6}\right) \delta(\mathrm{ppm}): 8.78\left(1 \mathrm{H}, \mathrm{bs}, \mathrm{NH}_{2}\right.$, exchange with $\left.\mathrm{D}_{2} \mathrm{O}\right), 8.59\left(1 \mathrm{H}, \mathrm{bs}, \mathrm{NH}_{2}\right.$, exchange with $\left.\mathrm{D}_{2} \mathrm{O}\right), 7.72(2 \mathrm{H}, \mathrm{d}$, $J=8.28 \mathrm{~Hz}), 7.41-7.33(8 \mathrm{H}, \mathrm{m}), 7.10\left(2 \mathrm{H}, \mathrm{bs}, \mathrm{NH}_{2}\right.$, exchange with $\left.\mathrm{D}_{2} \mathrm{O}\right), 6.65(1 \mathrm{H}, \mathrm{s}) 4.23(2 \mathrm{H}, \mathrm{s}) .{ }^{13} \mathrm{C}$ NMR $\left(100 \mathrm{MHz}, \mathrm{DMSO}-d_{6}\right)$ $\delta(\mathrm{ppm}): 153.3,144.5,143.2,140.4,140.3,138.6,135.0,129.9,126.5$ $124.5,121.5,119.7,116.9,31.6,22.0 .{ }^{77}$ Se NMR (76 MHz, DMSO-d $\left.d_{6}\right)$ $\delta(\mathrm{ppm}):$ 371.8. MS (ESI negative) $m / z: 488.2[\mathrm{M}-\mathrm{H}]^{-}$.

4.1.12. 2-(6-hydroxy-3-oxo-3H-xanthen-9-yl)-5-(3-(4-((4sulfamoylbenzyl)selanyl)phenyl) thioureido) benzoic acid 10c<smiles>NS(=O)(=O)c1ccc(C[Se]c2ccc(NC(=S)Nc3ccc(-c4c5ccc(=O)cc-5oc5cc(O)ccc45)c(C(=O)O)c3)cc2)cc1</smiles> 
Following the general procedure, 4-((4-aminophenyl) selanyl)methyl)benzenesulfonamide 7c $(68 \mathrm{mg}, 0.20 \mathrm{mmol})$ and Fluorescein isothiocyanate $\mathbf{8 c}(78 \mathrm{mg}, 0.20 \mathrm{mmol})$ gave after flash chromatography (hexane/Acetone $1: 1) \mathbf{1 0 c}(80 \mathrm{mg}, 55 \%) .{ }^{\mathbf{1}} \mathbf{H}$ NMR $\left(400 \mathrm{MHz}, \mathrm{DMSO}-d_{6}\right) \delta(\mathrm{ppm}): 10.34\left(1 \mathrm{H}\right.$, bs, exchange with $\left.\mathrm{D}_{2} \mathrm{O}\right)$, $10.22-10.17\left(3 \mathrm{H}, \mathrm{m}\right.$, exchange with $\left.\mathrm{D}_{2} \mathrm{O}\right), 8.24(1 \mathrm{H}, \mathrm{d}, J=1.49 \mathrm{~Hz})$, $7.85(2 \mathrm{H}, \mathrm{d}, J=8.20 \mathrm{~Hz}), 7.74(2 \mathrm{H}, \mathrm{d}, J=8.25 \mathrm{~Hz}), 7.49-7.47(5 \mathrm{H}, \mathrm{m})$, $7.34(3 \mathrm{H}, \mathrm{d}, J=4.63 \mathrm{~Hz}), 6.72(2 \mathrm{H}, J=1.93 \mathrm{~Hz}), 6.66-6.60(4 \mathrm{H}, \mathrm{m})$, $4.33(2 \mathrm{H}, \mathrm{s}) .{ }^{13} \mathrm{C}$ NMR $\left(100 \mathrm{MHz}, \mathrm{DMSO}-d_{6}\right) \delta(\mathrm{ppm}): 180.5,169.4$, 160.5, 152.9, 144.3, 143.9, 143.8, 143.4, 139.4, 133.6, 130.1, 130.0, $129.9,126.8,126.7,125.2,118.6,113.6,110.7,103.3,84.0,31.1 .{ }^{77} \mathbf{S e}$ NMR (76 MHz, DMSO- $\left.d_{6}\right) \delta(\mathrm{ppm}): 370.1$. MS (ESI negative) $\mathrm{m} / z$ : $730.3[\mathrm{M}-\mathrm{H}]^{-}$.

4.1.13. General procedure for the synthesis of selenides 11a-c

Compound 7c $(0.2 \mathrm{mmol})$ was dissolved in anhydrous THF $(5 \mathrm{~mL})$,then added trimethylamine $(0.24 \mathrm{mmol}, 1.2$ eq. $)$ and a stoichiometric amount of acyl chloride 9a-c. The mixture was stirred at room temperature until completion (TLC monitoring). The reaction was quenched by addition of saturated aq. $\mathrm{NH}_{4} \mathrm{Cl}(2 \mathrm{~mL})$ and diluted with EtOAc ( $5 \mathrm{~mL}$ ). The layers were separated and the aqueous layer was extracted with EtOAc $(2 \times 5 \mathrm{~mL})$, dried over $\mathrm{Na}_{2} \mathrm{SO}_{4}$, filtered and concentrated under vacuum. The crude material was purified by flash chromatography (hexane/EtOAc $1: 1$ ) to yield selenides 11a-c.

\subsubsection{2-((4-((4-sulfamoylbenzyl)selanyl)phenyl)carbamoyl)phenyl} acetate 11a

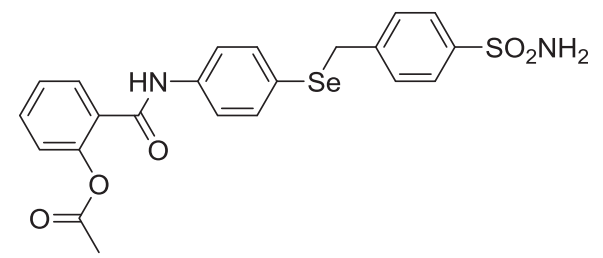

Following the general procedure, 4-(((4-aminophenyl)selanyl) methyl)benzenesulfonamide 7c $(68 \mathrm{mg}, 0.20 \mathrm{mmol})$ and O-Acetylsalicyloyl chloride $\mathbf{9 a}$ ( $40 \mathrm{mg}, 0.20 \mathrm{mmol}$ ) gave after flash chromatography (hexane/EtOAc 1:1) $\mathbf{1 1 a}$ (71 mg, 70\%). ${ }^{\mathbf{1}} \mathbf{H}$ NMR (400 MHz, DMSO- $\left.d_{6}\right) \delta(\mathrm{ppm}): 10.44\left(1 \mathrm{H}, \mathrm{bs}, \mathrm{NH}_{2}\right.$, exchange with $\left.\mathrm{D}_{2} \mathrm{O}\right), 7.85(1 \mathrm{H}, \mathrm{d}, J=8.33 \mathrm{~Hz}), 7.74-7.64(6 \mathrm{H}, \mathrm{m}), 7.49-7.42(4 \mathrm{H}, \mathrm{m})$, $7.34(2 \mathrm{H}, \mathrm{d}, J=9.62 \mathrm{~Hz}), 7.29(1 \mathrm{H}, \mathrm{dd}, J=8.09,0.88 \mathrm{~Hz}), 4.29(2 \mathrm{H}, \mathrm{s})$, $2.23(3 \mathrm{H}, \mathrm{s}) .{ }^{13} \mathrm{C}$ NMR (100 MHz, DMSO-d 6 ) $\delta(\mathrm{ppm}): 169.8,165.1$, 148.9, 144.4, 143.7, 143.3, 139.4, 134,3 132.5, 130.4, 130.0, 126.8, 126.6, 124.3, 124.2, 121.4, 65.8, 21.6. ${ }^{77}$ Se NMR (76 MHz, DMSO-d $\left.d_{6}\right)$ $\delta$ (ppm): 372.6. MS (ESI negative) $m / z: 502.2[\mathrm{M}-\mathrm{H}]^{-}$.

4.1.15. 2,4-Dimethoxy-N-(4-((4-sulfamoylbenzyl)selanyl)phenyl) benzamide 11b

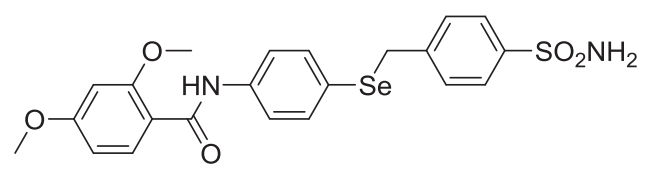

Following the general procedure, 4-(((4-aminophenyl)selanyl) methyl)benzenesulfonamide 7c $(68 \mathrm{mg}, 0.20 \mathrm{mmol})$ and 2,4Dimethoxybenzoyl chloride $9 \mathbf{b}(40 \mathrm{mg}, 0.20 \mathrm{mmol})$ gave after flash chromatography (hexane/EtOAc $1: 1) \mathbf{1 1 b}(66 \mathrm{mg}, 65 \%) .{ }^{\mathbf{1}} \mathbf{H}$ NMR (400 MHz, DMSO- $\left.d_{6}\right) \delta(\mathrm{ppm}): 10.01\left(1 \mathrm{H}, \mathrm{bs}, \mathrm{NH}_{2}\right.$, exchange with $\left.\mathrm{D}_{2} \mathrm{O}\right), 7.76(1 \mathrm{H}, \mathrm{d}, J=8.57 \mathrm{~Hz}), 7.71(4 \mathrm{H}, \mathrm{t}, J=8.41 \mathrm{~Hz}), 7.46(2 \mathrm{H}$, d, $J=8.64 \mathrm{~Hz}), 7.43(2 \mathrm{H}, \mathrm{d}, J=8.42 \mathrm{~Hz}), 7.33\left(2 \mathrm{H}, \mathrm{bs}, \mathrm{NH}_{2}\right.$, exchange with $\left.\mathrm{D}_{2} \mathrm{O}\right), 6.74,(1 \mathrm{H}, \mathrm{t}, J=2.10 \mathrm{~Hz}), 6.70(1 \mathrm{H}, \mathrm{dd}, J=8.63,2.29 \mathrm{~Hz})$, $4.28(2 \mathrm{H}, \mathrm{s}), 3.98(3 \mathrm{H}, \mathrm{s}), 3.88(3 \mathrm{H}, \mathrm{s}) .{ }^{13} \mathrm{C} \mathrm{NMR}\left(100 \mathrm{MHz}, \mathrm{DMSO}-d_{6}\right)$ $\delta(\mathrm{ppm}): 164.6,163.9,159.2,144.4,143.2,139.4,134.4,132.8,130.0$, 126.6, 123.8, 121.4, 117.0, 106.7, 99.5, 57.1, 56.5, $31.3{ }^{77}$ Se NMR $\left(76 \mathrm{MHz}, \mathrm{DMSO}-d_{6}\right) \delta(\mathrm{ppm}): 373.1$. MS (ESI negative) $\mathrm{m} / \mathrm{z}: 505.2$ $[\mathrm{M}-\mathrm{H}]^{-}$.

\subsubsection{6. $\mathrm{N}$-(4-((4-sulfamoylbenzyl)selanyl)phenyl)cinnamamide 11c}

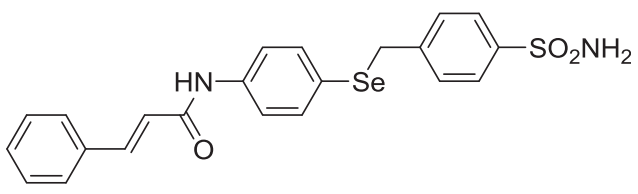

Following the general procedure, 4-((4-aminophenyl)selanyl) methyl)benzenesulfonamide 7c (68 $\mathrm{mg}, 0.20 \mathrm{mmol})$ and cinnamoyl chloride 9c (40 mg, $0.20 \mathrm{mmol}$ ) gave after flash chromatography (hexane/EtOAc 1:1) 11c (72 mg, 76\%). ${ }^{\mathbf{1}} \mathbf{H}$ NMR (400 MHz, DMSO$\left.d_{6}\right) \delta(\mathrm{ppm}): 10.33\left(1 \mathrm{H}, \mathrm{bs}, \mathrm{NH}_{2}\right.$, exchange with $\left.\mathrm{D}_{2} \mathrm{O}\right), 7.73(2 \mathrm{H}, \mathrm{d}$, $J=8.37 \mathrm{~Hz}), 7.69-7.64(5 \mathrm{H}, \mathrm{m}), 7.51-7.45(5 \mathrm{H}, \mathrm{m}), 7.43(2 \mathrm{H}, \mathrm{d}$, $J=8.38 \mathrm{~Hz}), 7.34\left(2 \mathrm{H}, \mathrm{bs}, \mathrm{NH}_{2}\right.$, exchange with $\left.\mathrm{D}_{2} \mathrm{O}\right), 6.86(1 \mathrm{H}, \mathrm{d}$, $J=15.72 \mathrm{~Hz}), \quad 4.28$ (2H, s). ${ }^{13} \mathrm{C}$ NMR (100 MHz, DMSO- $\left.d_{6}\right)$ $\delta(\mathrm{ppm}): 164.5,144.4,143.2,141.3,139.6,135.6,134.5,130.8,130.0$, 129.9, 128.7, 126.6, 123.9, 123.0, 120.8, 31.3 ${ }^{77}$ Se NMR (76 MHz, DMSO- $\left.d_{6}\right) \delta(\mathrm{ppm}): 373.5$. MS (ESI negative) $\mathrm{m} / \mathrm{z}: 471.2[\mathrm{M}-\mathrm{H}]^{-}$.

\subsubsection{General procedure for the synthesis of selenide $\mathbf{1 2}$}

4-(bromomethyl) benzenesulfonamide $6(125 \mathrm{mg}, 0.5 \mathrm{mmol}$ ) was dissolved in acetone $(10 \mathrm{~mL})$ and then was added $\mathrm{KSeCN}$ ( $87 \mathrm{mg}, 0.6 \mathrm{mmol}, 1.2 \mathrm{eq}$.). The mixture was stirred at reflux for $4 \mathrm{~h}$, until completion (TLC monitoring). The reaction was quenched by addition of saturated aq. $\mathrm{NH}_{4} \mathrm{Cl}(2 \mathrm{~mL})$ and diluted with EtOAc $(5 \mathrm{~mL})$. The layers were separated and the aqueous layer was extracted with EtOAc $(2 \times 5 \mathrm{~mL})$, dried over $\mathrm{Na}_{2} \mathrm{SO}_{4}$, filtered and concentrated under vacuum. The crude material was purified by flash chromatography (DCM/MeOH 90:10) to yield selenide 12 (70\%).

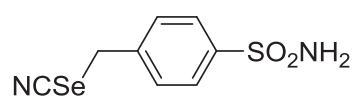

${ }^{1} \mathbf{H}$ NMR $\left(400 \mathrm{MHz}, \mathrm{DMSO}-d_{6}\right) \delta(\mathrm{ppm}): 7.85(2 \mathrm{H}, \mathrm{d}, J=8.39 \mathrm{~Hz})$, $7.58(2 \mathrm{H}, \mathrm{d}, J=8.41 \mathrm{~Hz}), 7.40\left(2 \mathrm{H}, \mathrm{bs}, \mathrm{NH}_{2}\right.$, exchange with $\left.\mathrm{D}_{2} \mathrm{O}\right), 4.40$ $(2 \mathrm{H}, \mathrm{s}) .{ }^{13} \mathrm{C}$ NMR $\left(100 \mathrm{MHz}, \mathrm{DMSO}-d_{6}\right) \delta(\mathrm{ppm}): 144.2,143.3,130.2$, 126.9, 105.6, $32.5{ }^{77}$ Se NMR (76 MHz, DMSO-d 6 ) $\delta$ (ppm): 327.7. MS (ESI negative) $m / z: 274.0[\mathrm{M}-\mathrm{H}]^{-}$.

\subsection{Carbonic anhydrase inhibition}

An Applied Photophysics stopped-flow instrument has been used for assaying the $\mathrm{CA}$ catalyzed $\mathrm{CO}_{2}$ hydration activity [22]. Phenol red (at a concentration of $0.2 \mathrm{mM}$ ) has been used as indicator, working at the absorbance maximum of $557 \mathrm{~nm}$, with 20 mMHepes (pH 7.5) as buffer, and $20 \mathrm{mM} \mathrm{Na}_{2} \mathrm{SO}_{4}$ (for maintaining constant the ionic strength), following the initial rates of the CAcatalyzed $\mathrm{CO}_{2}$ hydration reaction for a period of $10-100 \mathrm{~s}$. The $\mathrm{CO}_{2}$ concentrations ranged from 1.7 to $17 \mathrm{mM}$ for the determination of the kinetic parameters and inhibition constants. For each inhibitor at least six traces of the initial $5-10 \%$ of the reaction have been used for determining the initial velocity. The uncatalyzed rates were determined in the same manner and subtracted from the total observed rates. Stock solutions of inhibitor $(0.1 \mathrm{mM})$ were 
prepared in distilled-deionized water and dilutions up to $0.01 \mathrm{nM}$ were done thereafter with the assay buffer. Inhibitor and enzyme solutions were preincubated together for $15 \mathrm{~min}$ at room temperature prior to assay, in order to allow for the formation of the E-I complex. The inhibition constants were obtained by non-linear least-squares methods using PRISM 3 and the Cheng-Prusoff equation, as reported earlier [23-27], and represent the mean from at least three different determinations. All CA isoforms were recombinant ones obtained in-house as reported earlier [24-26].

\subsection{Protein X-ray crystallography}

hCA II protein was purified as previously described [32]. The protein was concentrated to about $7 \mathrm{mg} \mathrm{mL}^{-1}$ and set up in SD2 crystallization plates (Molecular Dimensions) with the following ratio of protein plus reservoir: $200 \mathrm{~nL}+200 \mathrm{~nL}$. The plate was incubated at $8{ }^{\circ} \mathrm{C}$ and the reservoir conditions consisted of 2.6-3.0 M ammonium sulfate with $0.1 \mathrm{M}$ Tris buffer at $\mathrm{pH} 8.0$ to $\mathrm{pH}$ 8.5. Compounds in DMSO were added to crystallization drops after crystals had formed and several days before data were collected. 360 frames of one degree oscillation were obtained from the MX1 beamline of the Australian Synchrotron. The data were indexed using XDS [33] and scaled using Aimless [34]. Molecular replacement was done using Phaser [35] using 4cq0 as the initial starting model. The model was manually rebuilt using Coot [36] and refined using a combination of Phenix [37] and Refmac [38]. The compound was placed in density using the program Afitt (OpenEye Scientific Software) and further refined using Refmac. For structure 6D1L, two data sets from two different crystals soaked with the same compound were merged. For structure $6 \mathrm{D} 1 \mathrm{M}$, a single $360^{\circ}$ data set was obtained and used for the structure determination and refinement.

\subsection{Biological assays}

Oxaliplatin ( $\left.2.4 \mathrm{mg} \mathrm{kg}^{-1}\right)$ was dissolved in $5 \%$ glucose solution and i.p. administered for 5 consecutive days every week for 2 weeks [39]. Starting from day 14, compounds and acetazolamide were suspended in CMC and p.o. administered [40,41]. Pain-related behavior (i.e. lifting and licking of the hind paw) were observed and the time (seconds) of the first sign was recorded. ${ }^{* *} \mathrm{P}<0.01 \mathrm{vs}$ vehicle + vehicle treated animals; ${ }^{\wedge} \mathrm{P}<0.05$ and ${ }^{\wedge} \mathrm{P}<0.01$ vs oxaliplatin + vehicle treated animals. Each value represents the mean of 10 mice.

\section{Acknowledgments}

We thank the Australian Synchrotron and the beamline scientists for their help with data collection, the C3 Crystallization Centre (crystal.csiro.au) for all crystallization experiments and thank OpenEye Scientific Software for a license to the program Afitt.

\section{Appendix A. Supplementary data}

Supplementary data related to this article can be found at https://doi.org/10.1016/j.ejmech.2018.05.026.

\section{References}

[1] I. Gilron, C.P. Watson, C.M. Cahill, D.E. Moulin, Neuropathic pain: a practical guide for the clinician, CMAJ (Can. Med. Assoc. J.) 175 (2006) 265-275.

[2] N.B. Finnerup, N. Attal, S. Haroutounian, E. McNicol, R. Baron, R.H. Dworkin, I. Gilron, M. Haanpaa, P. Hansson, T.S. Jensen, P.R. Kamerman, K. Lund, A. Moore, S.N. Raja, A.S. Rice, M. Rowbotham, E. Sena, P. Siddall, B.H. Smith, M. Wallace, Pharmacotherapy for neuropathic pain in adults: a systematic review and meta-analysis, Lancet Neurol. 14 (2015) 162-173.
[3] N. Torrance, B.H. Smith, M.I. Bennett, A.J. Lee, The epidemiology of chronic pain of predominantly neuropathic origin. Results from a general population survey, J. Pain 7 (2006) 281-289.

[4] D. Bouhassira, M. Lantéri-Minet, N. Attal, B. Laurent, C. Touboul, Prevalence of chronic pain with neuropathic characteristics in the general population, Pain 136 (2008) 380-387.

[5] J. Wieseler-Frank, S.F. Maier, L.R. Watkins, Central proinflammatory cytokines and pain enhancement, Neurosignals 14 (2005) 166-174.

[6] M. Asiedu, M.H. Ossipov, K. Kaila, T.J. Price, Acetazolamide and midazolam act synergistically to inhibit neuropathic pain, Pain 148 (2010) 302-308.

[7] M.N. Asiedu, G.L. Mejia, C.A. Hübner, K. Kaila, T.J. Price, Inhibition of carbonic anhydrase augments $\mathrm{GABA}_{\mathrm{A}}$ receptor-mediated analgesia via a spinal mechanism of action, J. Pain 15 (2014) 395-406.

[8] C.T. Supuran, Carbonic anhydrase inhibition and the management of neuropathic pain, Expert Rev. Neurother. 16 (2016) 961-968.

[9] F. Carta, L. Di Cesare Mannelli, M. Pinard, C. Ghelardini, A. Scozzafava, R. McKenna, C.T. Supuran, A class of sulfonamide carbonic anhydrase inhibitors with neuropathic pain modulating effects, Bioorg. Med. Chem. 23 (2015) 1828-1840.

[10] L. Di Cesare Mannelli, L. Micheli, F. Carta, A. Cozzi, C. Ghelardini, C.T. Supuran, Carbonic anhydrase inhibition for the management of cerebral ischemia: in vivo evaluation of sulfonamide and coumarin inhibitors, J. Enzym. Inhib. Med. Chem. 31 (2016) 894-899.

[11] G. Negi, A. Kumar, R.P. Joshi, S.S. Sharma, Oxidative stress and Nrf2 in the pathophysiology of diabetic neuropathy: old perspective with a new angle, Biochem. Biophys. Res. Commun. 408 (2011) 1-5.

[12] G. Negi, A. Kumar, S.S. Sharma, Melatonin modulates neuroinflammation and Oxidative stress in experimental diabetic neuropathy: effects on NF-kB and Nrf2 cascades, J. Pineal Res. 50 (2011) 124-131.

[13] S.N. Prasad, Muralidhara, Neuroprotective effect of geraniol and curcuminin an acrylamide model of neurotoxicity in Drosophila melanogaster: relevance to neuropathy, J. Insect Physiol. 60 (2013) 7-16.

[14] G.M. Saifi, K. Szigeti, G.J. Snipes, C.A. Garcia, J.R. Lupski, Molecular mechanisms, diagnosis, and rational approaches to management of and therapy for Charcot-Marie-Tooth disease and related peripheral neuropathies, J. Invest. Med. Off. Publ. Am. Fed. Clin. Res. 51 (2003) 261-283.

[15] A. Angeli, D. Tanini, T.S. Peat, L. Di Cesare Mannelli, G. Bartolucci, A. Capperucci, C. Ghelardini, C.T. Supuran, F. Carta, Discovery of new selenoureido analogues of 4-(4-fluorophenylureido)benzenesulfonamide as carbonic anhydrase inhibitors, ACS Med. Chem. Lett. 8 (2017) 963-968.

[16] A. Angeli, D. Tanini, C. Viglianisi, L. Panzella, A. Capperucci, S. Menichetti, C.T. Supuran, Evaluation of selenide, diselenide and selenoheterocycle derivatives as carbonic anhydrase I, II, IV, VII and IX inhibitors, Bioorg. Med. Chem. 25 (2017) 2518-2523.

[17] S. Yoshida, F. Kumakura, I. Komatsu, K. Arai, Y. Onuma, H. Hojo, B.G. Singh, K.I. Priyadarsini, M. Iwaoka, Antioxidative glutathione peroxidase activity of selenoglutathione, Angew Chem. Int. Ed. Engl. 50 (2011) 2125-2128.

[18] A. Angeli, D. Tanini, A. Capperucci, C.T. Supuran, Synthesis of novel selenides bearing benzenesulfonamide moieties as carbonic anhydrase I, II, IV, VII and IX inhibitors, ACS Med. Chem. Lett. 8 (2017) 1213-1217.

[19] A. Angeli, L. di Cesare Mannelli, E. Trallori, T.S. Peat, C. Ghelardini, F. Carta, C.T. Supuran, Design, synthesis, and x-ray of selenides as new class of agents for prevention of diabetic cerebrovascular pathology, ACS Med. Chem. Lett. 9 (2018) 462-467.

[20] A.V. Kachanov, O.Y. Slabko, O.V. Baranova, E.V. Shilova, V.A. Kaminskii, Triselenium dicyanide from malononitrile and selenium dioxide. One-pot synthesis of selenocyanates, Tetrahedron Lett. 45 (2004) 4461-4463.

[21] F. Pacchiano, F. Carta, P.C. McDonald, Y. Lou, D. Vullo, A. Scozzafava, S. Dedhar C.T. Supuran, Ureido-substituted benzenesulfonamides potently inhibit carbonic anhydrase IX and show antimetastatic activity in a model of breast cancer metastasis, J. Med. Chem. 54 (2011) 1896-1902.

[22] R.G. Khalifah, The carbon dioxide hydration activity of carbonic anhydrase. I. Stop flow kinetic studies on the native human isoenzymes B and C, J. Biol. Chem. 246 (1971) 2561.

[23] A. Angeli, T.S. Peat, G. Bartolucci, A. Nocentini, C.T. Supuran, F. Carta, Intramolecular oxidative deselenization of acylselenoureas: a facile synthesis of benzoxazole amides and carbonic anhydrase inhibitors, Org. Biomol. Chem. 14 (2016) 11353-11356.

[24] A. Angeli, F. Carta, G. Bartolucci, C.T. Supuran, Synthesis of novel acyl selenoureido benzensulfonamides as carbonic anhydrase I, II, VII and IX inhibitors, Bioorg. Med. Chem. 25 (2017) 3567.

[25] A. Angeli, D. Tanini, A. Capperucci, C.T. Supuran, First evaluation of organotellurium derivatives as carbonic anhydrase I, II, IV, VII and IX inhibitors, Bioorg. Chem. 76 (2018) 268-272.

[26] A. Angeli, A.A. Abdel-Aziz, A. Nocentini, A.S. El-Azab, P. Gratteri, C.T. Supuran, Synthesis and carbonic anhydrase inhibition of polycyclic imides incorporating N-benzenesulfonamide moieties, Bioorg. Med. Chem. 25 (2017) 5373-5379.

[27] C.B. Mishra, S. Kumari, A. Angeli, S.M. Monti, M. Buonanno, M. Tiwari, C.T. Supuran, Discovery of benzenesulfonamides with potent human carbonic anhydrase inhibitory and effective anticonvulsant action: design, synthesis, and pharmacological assessment, J. Med. Chem. 60 (2017) 2456-2469.

[28] S.G. Kwon, D.H. Roh, S.Y. Yoon, J.Y. Moon, S.R. Choi, H.S. Choi, S.Y. Kang, H.J. Han, A.J. Beitz, S.B. Oh, J.H. Lee, Acid evoked thermal hyperalgesia involves 
peripheral P2Y1 receptor mediated TRPV1 phosphorylation in a rodent model of thrombus induced ischemic pain, Mol. Pain 10 (2014) 2.

[29] P. Olausson, B. Gerdle, N. Ghafouri, B. Larsson, B. Ghafouri, Identification of proteins from interstitium of trapezius muscle in women with chronic myalgia using microdialysis in combination with proteomics, PLoS One 7 (2012), e52560.

[30] G. Cavaletti, G. Tredici, M.G. Petruccioli, E. Dondè, P. Tredici, P. Marmiroli, C. Minoia, A. Ronchi, M. Bayssas, G.G. Etienne, Effects of different schedules of oxaliplatin treatment on the peripheral nervous system of the rat, Eur. J. Canc. 37 (2001) 2457-2463.

[31] L. Di Cesare Mannelli, A. Pacini, C. Matera, M. Zanardelli, T. Mello, M. De Amici, C. Dallanoce, C. Ghelardini, Involvement of $\alpha 7 \mathrm{nAChR}$ subtype in rat oxaliplatin-induced neuropathy: effects of selective activation, Neuropharmacology 79 (2014) 37-48.

[32] J. Moeker, T.S. Peat, L.F. Bornaghi, D. Vullo, C.T. Supuran, S.A. Poulsen, Cyclic secondary sulfonamides: unusually good inhibitors of cancer related carbonic anhydrase enzymes, J. Med. Chem. 57 (2014) 3522-3531.

[33] W. Kabsch, XDS, Acta Crystallogr. Sect. D Biol. Crystallogr. 66 (2010) 125-132.

[34] P.R. Evans, An introduction to data reduction: space group determination, scaling and intensity statistics, Acta Crystallogr. D: Biol. Crystallogr 67 (2011) $282-292$.

[35] A.J. McCoy, R.W. Grosse Kunstleve, P.D. Adams, M.D. Winn, L.C. Storoni, R.J. Read, Phaser crystallographic software, J. Appl. Crystallogr. 40 (2007) 658-674.

[36] P. Emsley, B. Lohkamp, W.G. Scott, K. Cowtan, Features and development of Coot, Acta Crystallogr. D Biol. Crystallogr. 66 (2010) 486-501.
[37] P.D. Adams, P.V. Afonine, G. Bunkóczi, V.B. Chen, I.W. Davis, N. Echols, J.J. Headd, L.W. Hung, G.J. Kapral, R.W. Grosse-Kunstleve, A.J. McCoy, N.W. Moriarty, R. Oeffner, R.J. Read, D.C. Richardson, J.S. Richardson, T.C. Terwilliger, P.H. Zwart, PHENIX: a comprehensive Python-ased system for macromolecular structure solution, Acta Crystallogr. D66 (2010) 213-221.

[38] G.N. Murshudov, P. Skubak, A.A. Lebedev, N.S. Pannu, R.A. Steiner, R.A. Nicholls, M.D. Winn, F. Long, A.A. Vagin, REFMAC5 for the refinement of macromolecular crystal structures, Acta Crystallogr. D Biol. Crystallogr. 67 (2011) 355-367.

[39] L. Di Cesare Mannelli, E. Lucarini, L. Micheli, I. Mosca, P. Ambrosino, M.V. Soldovieri, A. Martelli, L. Testai, M. Taglialatela, V. Calderone, C. Ghelardini, Effects of natural and synthetic isothiocyanate-based H2Sreleasers against chemotherapy-induced neuropathic pain: role of Kv7 potassium channels, Neuropharmacology 121 (2017) 49-59.

[40] C. Battilocchio, G. Poce, S. Alfonso, G.C. Porretta, S. Consalvi, L. Sautebin, S. Pace, A. Rossi, C. Ghelardini, L. Di Cesare Mannelli, S. Schenone, A. Giordani, L. Di Francesco, P. Patrignani, M. Biava, A class of pyrrole derivatives endowed with analgesic/anti-inflammatory activity, Bioorg. Med. Chem. 21 (2013) 3695-3701.

[41] M. Anzini, S. Valenti, C. Braile, A. Cappelli, S. Vomero, S. Alcaro, F. Ortuso, L. Marinelli, V. Limongelli, E. Novellino, L. Betti, G. Giannaccini, A. Lucacchini, S. Daniele, C. Martini, C. Ghelardini, L. Di Cesare Mannelli, G. Giorgi, M.P. Mascia, G. Biggio, New insight into the central benzodiazepine receptorligand interactions: design, synthesis, biological evaluation, and molecular modeling of 3-substituted 6-phenyl-4H-imidazo[1,5-a][1,4]benzodiazepines and related compounds, J. Med. Chem. 54 (2011) 5694-5711. 